\title{
From near- to far-field stresses: the emplacement of Plio-Pleistocene dikes at Trindade Island and its relationship with South Atlantic neotectonics
}

\author{
CARLOS RIBEIRO*1 \\ RAMON PATRICIO ${ }^{2}$
}

${ }^{1}$ Graduation in Geology - Federal University of Rio Grande do Norte.*(Correspondence: carlos.ribeiro@ufrn.edu.br)

${ }^{2}$ Graduation in Geology - São Paulo State University

The Trindade Island, in South Atlantic, represents one of the youngest volcanisms in South American Plate, from 3.9 Ma to $0.25 \mathrm{Ma}$. Effusive-pyroclastic alkaline rocks, as well subvolcanic dikes, following the nephelinite-phonolite series compose the lithologies of the island. High-resolution remote sensing allowed the mapping of 647 dikes with nepheliniticphonolitic composition, with minor occurrences of analcitites and monchiquites, that cross-cut the rocks of the island. Based on high-resolution remote sensing, field and geochemical data, the dikes were clustered in four groups.

i) Phonolitic radial dikes represent the first episodes of dike emplacement, being related to near-field stresses during events of magma chamber inflation.

ii) N-S to NE-SW dikes also represent near-field stresses, with magmatic overpressure of $100 \mathrm{MPa}$.

iii) NW-SE dikes show features that suggest the interaction between near- and far-field stresses, where the direction of the dikes reflect the resultant vector of N-S and E-W compression.

iv) E-W to ENE-WSW dikes represent the final stages of dike emplacement at Trindade Island, cross-cutting the previously described dikes. Their direction reflects far-field stresses, characterized by an E-W compression, corroborated by paleostress inversion of dilatational fractures. Our estimations based on aspect ratio of dikes indicates the presence of a magmatic plumbing system composed by crustal magma chambers, at ca. $9 \mathrm{~km}$, magma chambers at the crust-mantle boundary, at ca. $15 \mathrm{~km}$, fed by deep mantle reservoirs. During the interplay between near-field stresses, characterized by an N-S compression, and far-field stresses, characterized by E-W compression, a hybrid stress field, with NW-SE compression, is created. This hybrid stress-field related to magmatic and tectonic processes might be responsible for the reactivation of the Vitoria-Trindade Fracture Zone as a dextral strike-slip fault, generating the NW-SE elongation of Trindade Island. 